\title{
FACTORS INFLUENCING TREATMENT OUTCOME OF NON- NASOPHARYNGEAL HEAD AND NECK SQUAMOUS CELL CARCINOMA IN GERIATRIC PATIENTS
}

\author{
Atef Youssef Riad *, Dina Ragab Diab *, Khaled A.M Kamal *, and Rowaa M.Nagi *
}

\begin{abstract}
Department of Clinical Oncology and Nuclear Medicine - Faculty of Medicine - Ain Shams University*

Corresponding author

Rowaa Mohamed Nagi

Mahmoud,

Mobile: 01098085038,

E.mail: rowaanagy@gmail.com.

Received: 6/10/2020

Accepted: 5/11/2020
\end{abstract}

Online ISSN: 2735-3540

\section{ABSTRACT:}

Background: Head and neck squamous cell carcinoma (HNSCC) are a heterogeneous group of malignancy. Their incidenceincreases with age. Therefore, elderly HNSCC patients represent a large population who need special care and treatment considerations.

Aim of work:To correlate clinicopathologic factors of nonnasopharyngeal HNSCC geriatric patients with disease free survival (DFS) and overall survival (OS).

Patients and methods:A retrospective analysis of fifty nonnasopharyngeal HNSCC elderly patients $(\geq 65$ years) treated at the head and neck cancer unit at the clinical oncology department, Ain Shams University Hospitals from June 2014 to June 2019. The study correlatedpatients' age, comorbidities, tumor stage and Eastern Cooperative Oncology Group performance state (ECOG PS) with disease free survival (DFS) and overall survival (OS).

Results:Three years DFS rate among the patients aged 65-75 years was $73 \%$ versus $40 \%$ among patients aged $76-80$ years and three years OS rate decreased from $48.2 \%$ to $40 \%$ respectively. The median OS was 39.5 months for patients without co-morbidities compared to 32.5 months for patients with associated co-morbidities $(P=0.9)$ and the median DFS was nearly about 40 months for both groups $(p=0.7)$.Three years DFS was $78.7 \%$ among the patients with PS I and $54 \%$ among PS II and III $(P=0.56)$ while three years OS rate was $60.7 \%$ among patients with PS I but it was $42 \%$ for PS II and III $(p=0.5)$. The mean DFS dropped from 43.9 months to 18.4 months for early stages and locally advanced respectively but with no statistical significance association $(P=0.49)$. There was marked decrease of 2 years OS from $100 \%$ for early stages to $40.3 \%$ for locally advanced stages $(p=0.009)$.

Conclusion: In HNSCC geriatric patients age >75 years and locally advanced stages were poor prognostic factors for DFS and OS while co-morbidities and ECOG PS didn't affect treatment outcome.

Key words: HNSCC, elderly patients, OS, DFS, treatment outcome

\section{INTRODUCTION:}

Cancer is considered an age-related disease. More than $50 \%$ of cancer patients are aged 65 years or older ${ }^{1}$. HNC are no exception, as incidence increases with age ${ }^{2}$.
At time of diagnosis, twenty-five percent of HNC patients are above 70 years $^{3}$. This incidence is assumed to reach $60 \%$ in Western countries in $2030^{4}$. There's no single definition for old age and is mostly based on the life span of individuals. In 
developed countries, 65 years is considered the age to define geriatric population while in developing countries it's between 55 to 60 years ${ }^{5}$. The World Health Organization (WHO) defined geriatric populations as those aged over $60-65$ years $^{6}$. Geriatric population is a growing group in the world, in 2019 there were 703 million persons aged 65 years or over and this number is projected to double to 1.5 billion in 2050 therefore, there will be a large pool of geriatric patients with HNC that will need appropriate treatment ${ }^{7}$. Since the aging process is associated with multiple physiological changes and deterioration of organs' functions, appropriate treatment doesn't come without challenges ${ }^{8}$. Despite that, geriatric cancer patients are underrepresented in clinical trials ${ }^{9}$, and may not receive the standard treatment compared to young patients. This is due to multiple factors which include associated comorbidities, poor performance status, increased toxicity, lack of care giving, and clinician or patients preference ${ }^{10}$. Chronological age alone isn't sufficient to assess and predict the patient's tolerance to treatment, as there is a wide difference between the patients of the same age and there are multiple factors that can influence treatment outcome of geriatric cancer patients. The main objective during the management of geriatric patients is to assess risk to benefit ratio. According to National Comprehensive Cancer Network (NCCN) guidelines there are unique issues to be considered when dealing with geriatric cancer patients:

- The natural history of some cancers and their response to treatment may be changed with age. ${ }^{11}$

- Co-morbidities and physiological changes with age may affect the tolerability of cancer treatment ${ }^{12}$

- The quality of life and social support should be considered in decision making.
- Chronological age alone isn't a contraindication in cancer treatment. ${ }^{13}$

This study discusses factors affecting treatment outcome of non-nasopharyngeal HNSCC (larynx, oropharynx and hypopharynx) in geriatric patients.

\section{PATIENTS AND METHODS:}

The study population consisted of 50 HNSCC elderly patients diagnosed from June 2014 to June 2019 treated at the head and neck cancer unit, the clinical oncology department, Ain Shams University Hospitals.All patients aged 65 years or more with pathologically proven HNSCC of larynx, oropharynx and hypopharynx and who received radiotherapy either adjuvant or definitive with or without chemotherapy were included in our study. Patients aged below 65 years and/or had nasopharyngeal, oral cavity; salivary glands and paranasal sinuses carcinoma were excluded from this study. Data were retrospectively collected from patients' medical records and a correlation of clinico-pathologic factors (including age, comorbidities, tumor stage andECOG PSat time of diagnosis) with DFS and OS was done.

\section{Statistics:}

Data were extracted and tabulated, and survival data recorded and tabulated to analyze the different prognostic criteria. All statistical analysis was carried out using statistical package for Social Science (SSPSS version 23).

OS was defined as the time from date of presentation until date of last follow-up, lost follow up, or death. DFS was defined as the time after end of primary treatment until tumor progression or death.The Kaplan Meier method and the Log Rank test used to determine the significance of difference in survival between groups. 


\section{RESULTS:}

In the interval from June 2014 to June 2019, fifty geriatric patients (aged 65 years or more) of non-nasopharyngeal HNSCC were included in our study. Forty three patients were aged 65 to 75 years and 7 patients were aged 75 to 80 years. Forty six of the patients were males while 4 patients were females. The majority of patients (98\%) had ECOG PS I-II at presentation and no patients had PS 0 or IV. These patients were treated according to the primary site and stage. All patients except 4 were diagnosed as laryngeal carcinoma. Forty two percent of patients with different tumor sites had early stage disease (stage I-II) and fifty eight percent had locally advanced stage disease (III-IV). Fifteen patients underwent total laryngectomy and thyroidectomy with neck dissection then received adjuvant radiotherapy with or without chemotherapy while 35 patients received definitive radiotherapy alone or with concomitant chemotherapy (Tables 1, 2, 3).

Table (1): Patients' characteristic $(n=50)$

\begin{tabular}{|l|l|c|c|}
\hline & & Number & \% of patients \\
\hline \multirow{3}{*}{ Age groups } & 65-75 years & 43 & $86 \%$ \\
\cline { 2 - 4 } & $76-80$ years & 7 & $14 \%$ \\
\hline \multirow{5}{*}{ Co-morder } & Male & 46 & $92 \%$ \\
\cline { 2 - 4 } & Female & 4 & $8 \%$ \\
\cline { 2 - 4 } & Yes & 27 & $54 \%$ \\
\cline { 2 - 4 } & No & 23 & $46 \%$ \\
\cline { 2 - 4 } & Hypertension (HTN) & 14 & $28 \%$ \\
\cline { 2 - 4 } & Diabetes mellitus (DM) & 13 & $26 \%$ \\
\cline { 2 - 4 } & Ischemic heart disease (IHD) & 5 & $10 \%$ \\
\cline { 2 - 4 } & Hepatitis C virus (HCV) & 5 & $2 \%$ \\
\cline { 2 - 4 } & Others(Multiple sclerosis) & 1 & $60 \%$ \\
\hline \multirow{5}{*}{ ECOG PS status } & PS I & 30 & $38 \%$ \\
\cline { 2 - 4 } & PS II & 19 & $2 \%$ \\
\cline { 2 - 4 } & PS III & 1 & \\
\hline
\end{tabular}

Table (2) Tumors characteristics $(\mathrm{n}=50)$

\begin{tabular}{|l|l|c|c|}
\hline \multirow{4}{*}{ Tumor site } & & Number of patients & $\%$ of patients \\
\cline { 2 - 4 } & Laryngeal carcinoma & 46 & $92 \%$ \\
\cline { 2 - 4 } & Oro-pharyngeal carcinoma & 1 & $2 \%$ \\
\cline { 2 - 4 } & Hypo-pharyngeal carcinoma & 3 & $6 \%$ \\
\hline \multirow{3}{*}{$\begin{array}{c}\text { Tumor stage at } \\
\text { presentation }\end{array}$} & Stage I & 9 & $18 \%$ \\
\cline { 2 - 4 } & Stage II & 12 & $34 \%$ \\
\cline { 2 - 4 } & Stage III & 17 & $24 \%$ \\
\cline { 2 - 4 } & Stage IV & 12 & \multicolumn{2}{|c}{} \\
\hline
\end{tabular}


Table (3) Treatment characteristics $(n=50)$

\begin{tabular}{|c|c|c|c|c|}
\hline & & & $\begin{array}{l}\text { Number of } \\
\text { patients out of } 50\end{array}$ & $\%$ of patients \\
\hline \multirow[t]{3}{*}{ Surgery } & Type & $\begin{array}{l}\text { Total laryngectomy, } \\
\text { thyroidectomy and neck } \\
\text { dissection }\end{array}$ & & \\
\hline & & yes & 15 & $30 \%$ \\
\hline & & no & 35 & $70 \%$ \\
\hline \multirow[t]{8}{*}{ Radiotherapy } & \multirow[t]{2}{*}{ Aim } & Definitive & 35 & $70 \%$ \\
\hline & & Adjuvant & 15 & $30 \%$ \\
\hline & \multirow[t]{2}{*}{ Total dose } & 60-66 Gy & 34 & $68 \%$ \\
\hline & & $70 \mathrm{~Gy}$ & 16 & $32 \%$ \\
\hline & \multirow[t]{2}{*}{ Fractionation } & Hypofractionation & 21 & $42 \%$ \\
\hline & & Conventional & 29 & $58 \%$ \\
\hline & \multirow[t]{2}{*}{ Technique } & $3 \mathrm{D}$ & 48 & $96 \%$ \\
\hline & & IMRT & 2 & $4 \%$ \\
\hline \multirow{4}{*}{$\begin{array}{l}\text { Concomitant } \\
\text { chemotherapy }\end{array}$} & & Yes & 11 & $22 \%$ \\
\hline & & No & 39 & $78 \%$ \\
\hline & \multirow[t]{2}{*}{ Type } & Weekly carboplatin & 8 & $73 \%$ \\
\hline & & Cisplatin every 21 days & 3 & $27 \%$ \\
\hline
\end{tabular}

Treatment outcome: For the entire cohort the overall mean DFS was 40.8 months, the median was 53.8 months and the 3years DFS rate was $68.7 \%$ (Table 4). While the 3 -years OS rate was $53.2 \%$, the mean was 38.7 monthsand the median was not reached for all the patients (Table 5).

Table (4) DFS of the studied patients ( $n=50)$.

\begin{tabular}{|c|c|c|c|}
\hline $\begin{array}{c}\text { Mean DFS } \\
\text { (months) }\end{array}$ & $95 \%$ CI & $\begin{array}{c}\text { Median DFS } \\
\text { (months) }\end{array}$ & $95 \%$ CI \\
\hline 40.845 & $32.968-48.721$ & 53.800 & $18.267-53.800$ \\
\hline
\end{tabular}

Table (5) OS of the studied patients ( $\mathrm{n}=50$ patients).

\begin{tabular}{|l|c|c|c|}
\hline $\begin{array}{l}\text { Mean OS } \\
\text { (months) }\end{array}$ & $95 \%$ CI & $\begin{array}{c}\text { Median OS } \\
\text { (months) }\end{array}$ & $95 \%$ CI \\
\hline 38.708 & $26.534-50.883$ & Not reached & \\
\hline
\end{tabular}

Factors affecting treatment outcome:

1-Age: Three years DFS rate among the patients aged $65-75$ years was $73 \%$ and the median was 53.8 months versus $40 \%$ and 8.4 months among patients aged 76-80 years $(\mathrm{p}=0.01)$ (Diagram 1).

Three years OS rate decreased from $48.2 \%$ to $40 \%$ and the median dropped from 26.3 months to 8.4 months for both groups respectively $(\mathrm{p}=0.01)($ Diagram 2$)$.

2- Co-morbidities: Twenty seven patients out of 50 patients had associated comorbidities. The most frequent co- morbidities were diabetes mellitus, hypertension and ischemic heart disease. The patients could have one or more of them. Hepatitis $\mathrm{C}$ virus infection was recorded in 5 patients and only one patient had multiple sclerosis. Co-morbidities didn't affect any of treatment outcomes compared to patients who had no associated comorbidities, the median DFS was nearly about 40 months for both groups $(\mathrm{p}=0.7)$. The median OS was 39.5 months for patients without co-morbidities compared to 32.5 months for patients with associated comorbidities ( $\mathrm{P}=0.9)$ (Table 6, 7). 


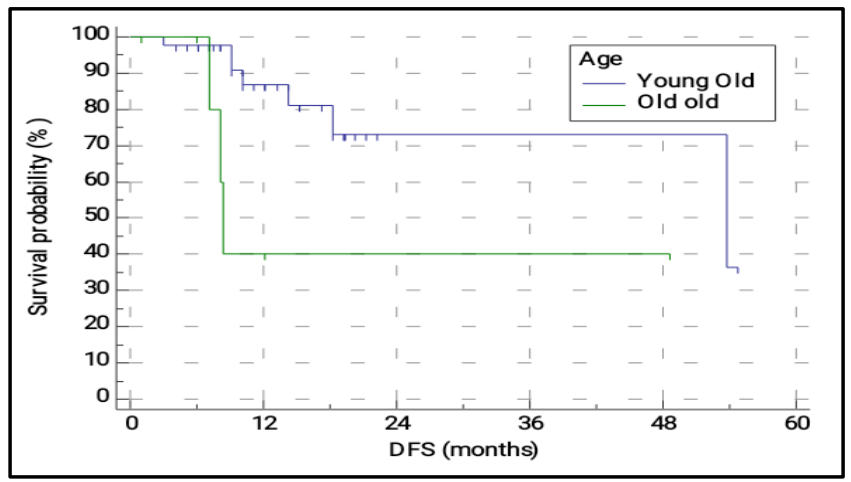

Diagram (1): Effect of age on DFS of the 50 patients

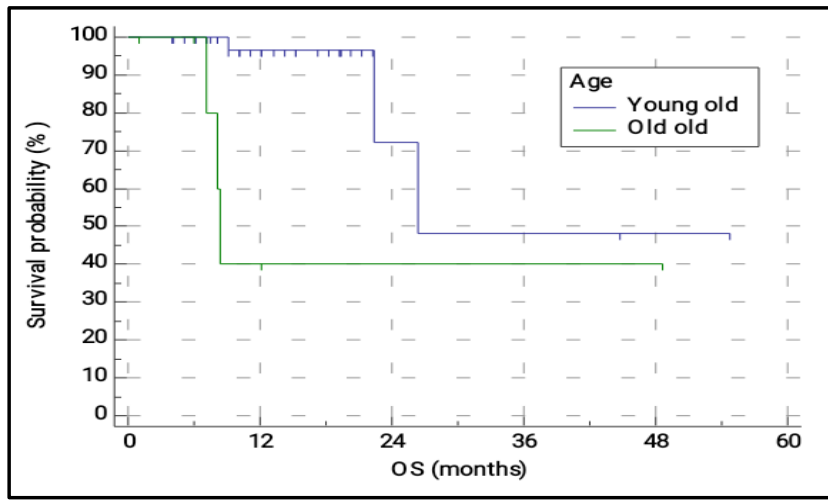

Diagram (2): Effect of age on OS rate of the 50 patients

Table (6): Correlation between co-morbidities and DFS in months $(n=50)$

\begin{tabular}{|l|c|c|c|c|}
\hline \multicolumn{1}{|c|}{ Factor } & $\begin{array}{c}\text { Mean DFS } \\
\text { (months) }\end{array}$ & $95 \%$ CI & $\begin{array}{c}\text { Median DFS } \\
\text { (months) }\end{array}$ & $95 \%$ CI \\
\hline No co-morbidities & 40.680 & $28.311-53.048$ & - & \\
\hline Yes co-morbidities & 40.950 & $30.073-51.828$ & 53.800 & $18.267-53.800$ \\
\hline Overall & 40.845 & $32.968-48.721$ & 53.800 & $18.267-53.800$ \\
\hline Significance & \multicolumn{3}{|c|}{$\mathrm{P}=0.7692$} &
\end{tabular}

Table (7): Correlation between co-morbidities and OS in months $(\mathrm{n}=50)$

\begin{tabular}{|c|c|c|c|c|}
\hline Co-morbidities & $\begin{array}{c}\text { Mean OS } \\
\text { (months) }\end{array}$ & $95 \% \mathrm{Cl}$ & $\begin{array}{c}\text { Median OS } \\
\text { (months) }\end{array}$ & $95 \% \mathrm{Cl}$ \\
\hline no & 39.565 & $23.377-55.754$ & - & \\
\hline Yes & 32.568 & $20.570-44.566$ & 26.367 & $26.367-26.367$ \\
\hline Overall & 38.708 & $26.534-50.883$ & - & \\
\hline Significance & & $\mathrm{P}=0.9895$ & & \\
\hline
\end{tabular}

3- ECOG PS: The initial PS was assessed at presentation according to ECOG PS status ${ }^{14}$. Thirty patients had PS I and 20 patients had PS II and III.

However, no statistical correlation was detected between PS status and treatment outcome (DFS and OS), three years DFS and OS rate dropped with PS II, III. Three years DFS was $78.7 \%$ among patients with PS I and $54 \%$ among PS II and III $(\mathrm{P}=0.56)$ while three years OS rate was $60.7 \%$ among patients with PS I and $42 \%$ for PS II and III $(\mathrm{p}=0.5)$.

4- Tumor stages:Twenty one patients were diagnosed at early stages, 9 were stage I and 12 were stage II disease. Twenty nine patients were diagnosed at locally advanced 
stages, 17 were stage III and 12 were stage IV.

The mean DFS dropped from 43.9 months to 18.4 months for early stages and locally advanced diseases respectively but with no statistical significant association $(\mathrm{P}=0.49)$. There was marked decrease in 2 years OS from $100 \%$ for early stages to $40.3 \%$ for locally advanced stages $(\mathrm{p}=0.009)$ (Table 8- Diagram 3).

Table (8): Correlation between stage and DFS $(\mathrm{n}=50)$

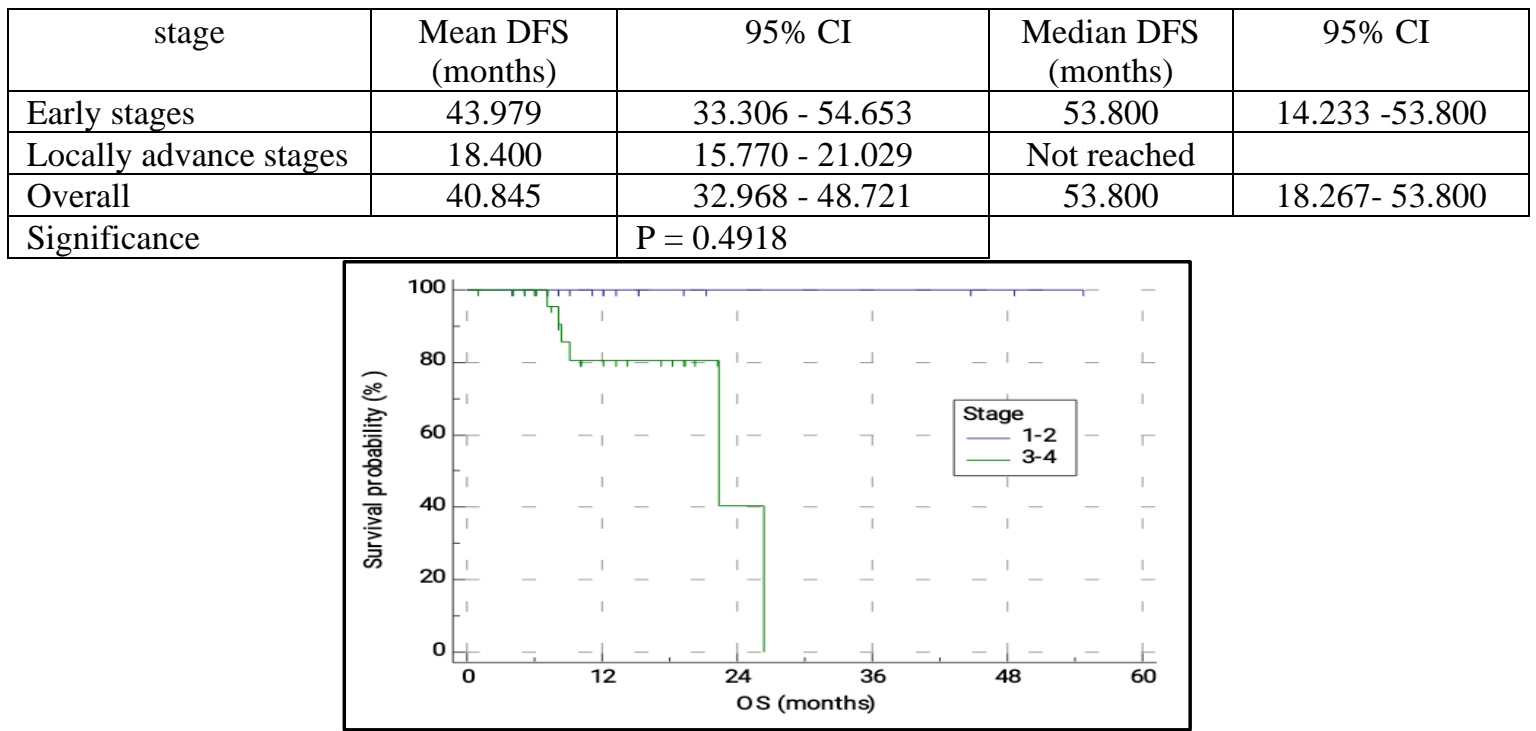

Diagram (3): Correlation between stage and 2 years OS rate $(n=50)$

\section{DISCUSSION:}

Worldwide, $\mathrm{HNC}$ are found to be more common in male patients than females ${ }^{15}$ and this was observed in our study; $92 \%$ of patients were males (46/50).

Our study was similar to Wang et $\mathrm{al}^{16}$. who observed that HNC patients aged above 60 years were associated with higher incidence of co-morbidities and $54 \%$ of ourpatients had the same finding.

In our study, the majority of patients were diagnosed with laryngeal carcinoma (46/50), 3 patients had hypopharyngeal carcinoma and only one patient had oropharyngeal carcinoma.This goes in accordance to GLOBOCAN 2018, regarding the incidence of HNSCC sub sites in Egypt, where laryngeal cancer is the most common HNSCC $(0.8 \%)$, followed by hypopharyngeal carcinoma $(0.25 \%)$ then oropharyngeal cancer $(0.09 \%)^{17}$.
According to SEER database, most of laryngeal carcinoma presented at early stages $53.8 \%$ for all age groups. Even for patients with age above 65 years $59.3 \%$ had early stages ${ }^{18}$. However, in our study more than half of patients $(58 \%)$ had locally advanced stages.

\section{Treatment outcome:}

In US and according to SEER data from 2000 to 2016, 3 years OS rate for laryngeal cancer was $68.6 \%$ and $69.4 \%$ for oral cavity and pharyngeal carcinoma for all age group. For patients aged 65 or more, the 3 years OS rate slightly decreased to $66.9 \%$ and $61.9 \%$ respectively ${ }^{18}$. In our study, 3years OS was $53.2 \%$ for all patients, which is lower than the reported survival of similar groups in the SEER database; but when compared to an Egyptian retrospective study at Clinical Oncology Department, Menoufia University ${ }^{19}$, the median OS for HNC was 
24 months for patients $>60$ years while in our study the median was not reached. Rastogi et al. ${ }^{20}$ studied the treatment outcome of HNSCC elderly patients (>70 years). The median DFS was 26.8 months and the 2 years DFS rate was $83.1 \%$. In our study, median DFS was 53.8 months and the 3 years DFS rate was $68.7 \%$.

\section{Factors affecting treatment outcome:}

1-Age: Our study confirmed strong correlation between age group and overall survival $(\mathrm{p}=0.01)$. The median OS was 26.3 months for patients aged 65-75 years and markedly decreased to 8.4 months for patients aged 76-85 years while the 3 years OS dropped from $48.2 \%$ to $40 \%$ respectively.

Douglas et al. ${ }^{21}$ also observed that median survival regularly decreased among increased age groups of HNC patients. It was 7.2 years for age group (45-54 years), 4.4 years for patients aged (55-64 years), 2.8 years for patients aged (65-74 years ) and 1.7 year for patients aged above 74 years.

Choi et al. ${ }^{22}$ confirmed in their multivariate analysis that age above 65 years was an independent risk factor for decreased OS in HNSCC with HR 1.4 (95\% CI 1.231.67).

Age was also a prognostic factor for DFS in our study. Three years DFS was $73 \%$ for patients aged $65-75$ versus $40 \%$ for aged 76-85 years $(p=0.01)$. Choi et al. ${ }^{22}$ also identified in multivariate analysis that age is a prognostic factor for DFS (HR, 1.23; 95\% CI, 1.06-1.44 $\mathrm{P}=0.006$ ).

2-Co-morbidities: Wang et al. ${ }^{16}$ multivariate analysis confirmed that patients who had 2 or more co-morbidities were associated with lower OS (HR=2.65; 96\% CI: 51.35-5.19). Similarly, Schimansky et al. ${ }^{23}$ determined that co-morbidities was an independent factor for OS (HR 1.4, 95\% CI: 1.1-1.7).
The present study couldn't detect correlation between co-morbidities and OS as previously mentioned studies but closely matched to Faheim et al. results ${ }^{24}$. Faheim et al. ${ }^{24}$ studied the effect of co-morbidities on Egyptian HNC patients. They found that $37 \%$ of patients had associated comorbidities. The used co-morbidities index score was higher with age above 60 years but no survival difference was detected.

In our present study, no difference was detected in DFS with or without associated co-morbidities. Our results are similar to those reported by Rastogi et al. ${ }^{20}$ who studied the treatment outcome of HNSCC geriatric patients (>70 years). In their study, no correlation between co-morbidities and DFS was observed.

3-PS status :Our study observed a numerically better 3 years OS rate for patients who had a good PS (I) (60.7\%) in comparison to PSII-III (42\%), but this difference was not statistically significant $(p=0.5)$. On the other hand, Lai et al. ${ }^{25}$ in their multivariate analysis for elderly HNC patients above 70 years found that PS above I was an independent factor for decreased OS HR was 2.312 (95\%CI:1.176-4.546; $\mathrm{P}=0.015$ 1). Similarly, Sommers et al. ${ }^{26}$ confirmed that PS II and III associated with lower OS compared to PS0 HR was 3.14 (95\% CI: $1.58-6.28 \mathrm{P}=0.001$ ).

In our study, all patients had an acceptable PS (I or II) except one patient who was treated with a bad PS (III). Therefore, all patients where eligible to appropriate treatment, including concurrent chemoradiation, if indicated. For the only patient with a bad PS, chemotherapy was omitted. This discrepancy in the number of patients with baseline PS, a low total number of patients recruited, explains the lack of statistically significant differences.

In our study, the three years DFS was numerically lower for patients who had PS II and III (54\%) compared to patients had PS I 
(78.7\%) but no statistical significance was found $(\mathrm{P}=0.56)$. similarly, there was no correlation between DFS and PS status in HNSCC geriatric patients (>70 years) was detected in the study performed by Rastogi et al. ${ }^{20}$.

\section{4-Stage:}

In our study, stage was correlated with treatment outcome. Two years OS rate decreased from $100 \%$ for early stages (stage I-II) to $40.3 \%$ for locally advanced stages (stages III-IV) $(\mathrm{p}=0.009)$. Our results were found to be similar to results from many studies.

According to SEER data in a period from 2000-2016, the 2 years OS for localized stage laryngeal carcinoma was $82.6 \%$ while for regional stage was $55.6 \%$, for patients aged above 65 years. ${ }^{4}$

Locally advanced stage in Choi et al. data $^{22}$ was associated with worse OS and DFS. OS decreased with stages III and IV compared to stage I, (HR, 3.9; 95\% CI, 1.828.72) for stage III and (HR, 4.5; 95\% CI, 2.2-9.3; p, 0.001) for stage IV. In the study by Douglas et al. ${ }^{21}$ median survival of HNSCC patients decreased with advanced stages. It was 10.4 years for stage I, 5.3 years for stage II, 3.5 years for stage III and 1.2 years for stage IV.

Our study showed a numerical difference of DFS in relation to stage but without statistical significance. The mean DFS was 43.9 months and 18.4 months for early stage and locally advanced stage $(p=0.49)$ respectively. Similarly, Dahlke et al. ${ }^{27}$ detected no significant correlation between locally advanced stages and local recurrence or distant metastasis. One year local recurrence free survival was $76 \%$ for T1-T2 disease versus 58\% for T3-4 diseases $(\mathrm{p}=0.1$ ) while it was $57 \%$ for nodal negative disease compared to $60 \%$ for nodal positive disease $(\mathrm{p}=0.5)$.

Conclusion: In HNSCC geriatric patients age $>75$ years and locally advanced stages were poor prognostic factors for DFS and OS while co-morbidities and ECOG PS didn't affect treatment outcome.

Conflicts of interest:There are no conflicts of interest.

\section{REFERENCES:}

1. Surveillance, Epidemiology, and End Results: SEER Cancer Statistics Review,. http:// seer.cancer.gov/csr/ 1975_2010/.

2. Warnakulasuriya S. Global epidemio-logy of oral and oropharyngeal cancer. Oral Oncol. 2009; 45(4-5): 309-316. doi:10.1016/j. oraloncology.2008.06.002

3. Grénman R, Chevalier D, Gregoire V, Myers E, Rogers S. Treatment of head and neck cancer in the elderly: European Consensus (panel 6) at the EUFOS Congress in Vienna 2007. Eur Arch Otorhinolaryngol. 2010;267(10): 1619-1621. doi:10.1007/ s 00405-010-1263-6

4. Smith BD, Smith GL, Hurria A, Hortobagyi GN, Buchholz TA. Future of cancer incidence in the United States: burdens upon an aging, changing nation. J Clin Oncol. 2009;27(17):2758-2765. doi:10.1200/JCO. 2008.20.8983

5. Dave P. Indigenous Conceptions of Aging. In: International Encyclopedia of the Social \& Behavioral Sciences. Elsevier; 2001: 7287-7289. doi:10.1016/B0-08-0430767/01667-3

6. United Nations. Department of Economic and Social Affairs. World Population Ageing 2019: Highlights. Vol 40.; 2019. doi:10.5860/choice.40-1307

7. Milet PR, Mallet Y, El Bedoui S, Penel N, Servent V, Lefebvre J-L. Head and neck cancer surgery in the elderly--does age influence the postoperative course? Oral Oncol. 2010;46(2):92-95. doi:10.1016/j. oraloncology.2009.10.002

8. Swaminathan D, Swaminathan V. Geriatric oncology: problems with under-treatment within this population. Cancer Biol Med. 2015;12(4):275-283. doi:10.7497/j.issn. 2095-3941.2015.0081. 
9. Scher KS HA. Under-representation of older adults in cancer registration trials: known problem, little progress. J Clin Oncol. 2012.

10. Freedman RA, Foster JC, Seisler DK, et al. Accrual of Older Patients With Breast Cancer to Alliance Systemic Therapy Trials Over Time: Protocol A151527. J Clin Oncol. 2017;35(4):421-431.doi:10.1200/JCO. 2016. 69.4182

11. Balducci L. Management of cancer in the elderly. Oncology (Williston Park). 2006;20(2):135-143; discussion 144, 146, 151-152. http://www.ncbi.nlm.nih. gov/pubmed/16562648.

12. Balducci L, Beghe $\mathrm{C}$. The application of the principles of geriatrics to the management of the older person with cancer. Crit Rev Oncol Hematol. 2000;35(3):147-154. doi:10.1016/ s1040-8428(00)00089-5

13. Extermann M. Management issues for elderly patients with breast cancer. Curr Treat Options Oncol. 2004;5(2):161-169. doi:10.1007/s11864-004-0048-9

14. Oken MM, Creech RH, Tormey DC et al. Toxicity and response criteria of the Eastern Cooperative Oncology Group. Am J Clin Oncol. 1982:5:649.

15. Bray F, Ren J-S, Masuyer E, Ferlay J. Global estimates of cancer prevalence for 27 sites in the adult population in 2008. Int $\mathbf{J}$ cancer. 2013;132(5):1133-1145. doi:10. 1002/ijc. 27711

16. Jennifer R. Wang, MD, Steven Habbous, MSc, Osvaldo Espin-Garcia, MMath, Duoduo Chen, BSc, Shao Hui Huang, MD, MRT(T), Colleen Simpson, BA,1Wei Xu, $\mathrm{PhD}$, Fei-Fei Liu, MD, Dale H. Brown, MD, Ralph W. Gilbert, MD, Patrick J. Gullane, MD, Jonathan C. Irish, MD, MSc, David P. Goldstein, MD, MSc, Geoffrey Liu, MD, MSc. Comorbidity and performance status as independent prognostic factors in patients with head and neck squamous cell carcinoma. Head Neck. 2016; 38 (5): 736742. doi:10.1002/hed.23947

17. Bray F, Ferlay J, Soerjomataram I, Siegel RL, Torre LA, Jemal A. Global cancer statistics 2018: GLOBOCAN estimates of incidence and mortality worldwide for 36 cancers in 185 countries. CA Cancer J Clin.
2018; 68(6):394-424. doi:10.3322/caac. 21492

18. SEER Survival Rates by Time Since Diagnosis, 2000-2016. seer.cancer.gov.

19. Hegazy A, El Din K, El-Fetouh M, Ahmed S. Clinical outcome and survival of head and neck cancer patients treated at Clinical Oncology Department, Menoufia University. Menoufia Med J. 2014;27(2):359. doi:10.4103/1110-2098.141709

20. Rastogi M, Gandhi AK, Nanda SS, Khurana R, Mishra SP, Srivastva AK. Analysis of Survival and Toxicity of Elderly Patients of Head and Neck Squamous Cell Carcinoma Treated With Induction Chemotherapy Followed By Definitive Radiation Therapy. Int J Radiat Oncol. 2017;99(2):E367. doi:10.1016/j.ijrobp.2017.06.1478

21. Douglas CM, Ingarfield K, McMahon AD, Savage SA, Conway DI, MacKenzie K. Presenting symptoms and long-term survival in head and neck cancer. Clin Otolaryngol. 2018;43(3):795-804. doi:10.1111/coa.13053

22. Seung Hee Choi, Jeffrey E. Terrell, Karen E. Fowler, Scott A. McLean, Tamer Ghanem,Gregory T. Wolf, Carol R. Bradford, Jeremy Taylor, Sonia A. Duffy. Socioeconomic and Other Demographic Disparities Predicting Survival among Head and Neck Cancer Patients. Langevin SM, ed. PLoS One. 2016;11(3):e0149886. doi:10. 1371/ journal.pone.0149886

23. Schimansky S, Lang S, Beynon R,Christopher Penfold ,Amy Davies ,Andrea Waylen, Steve Thomas MB BCh, Miranda Pring BDS, Michael Pawlita, Tim Waterboer , Andy Ness BM BS. Association between comorbidity and survival in head and neck cancer: Results from Head and Neck 5000. Head Neck. 2019;41(4):1053-1062. doi:10. 1002/hed.25543

24. Faheim, Reham M.; Adel AM. No Title. Pan Arab J Oncol. 2019;12(3):p6-10. 5p.

25. Lai K-M, Lin J-T, Lu H-J, Liang C-C, Chen M-K. Is definitive concurrent chemoradiotherapy effective for locally advanced head and neck cancer in the elderly aged $\geq$ 75 years: A single-institute, retrospective, cohort study. Asia Pac J Clin Oncol. 2018;14(3):247-255. doi:10.1111/ ajco. 


\title{
Atef Youssef Riad, et al.
}

12764

26. Sommers LW, Steenbakkers RJHM, Bijl HP,Johanna G.M. Vemer-van den Hoek, , Jan L.N. Roodenburg, Sjoukje F. Oosting, Gyorgy B. Halmos, Sophia E. de Rooij, Johannes A. Langendijk. Survival Patterns in Elderly Head and Neck Squamous Cell Carcinoma Patients Treated With Definitive Radiation Therapy. Int $\mathrm{J}$ Radiat Oncol. 2017;98(4):793-801. doi:10.1016/j.ijrobp.

\subsubsection{4}

27. Dahlke S, Steinmann D, Christiansen $\mathrm{h}$, martin durisin, andre eckardt, gerd wegener, michael bremerand andreas meyer. impact of time factors on outcome in patients with head and neck cancer treated with definitive radio (chemo) therapy. in vivo. 31(5):949-955. doi:10.21873/invivo. 11152

\section{العوامل التى تؤثر على نتائج علاج مرضى سرطان الخلايا الحرشفية فى الرأس و الرقبة دون البلعوم الأنفى للمرضى المسنين}

\author{
عاطف يوسف ررياض*, دينا رجب دياب*, خالد عبد العزيز محمد*, رواء محمد ناجي* \\ قسم علاج الاور ام والطب النووي - كلية الطب جامعة عين شمس
}

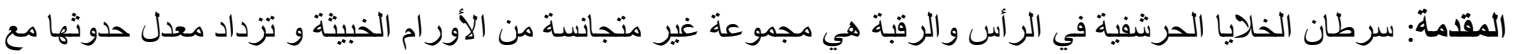
تقدم السن ؛ لذلك يمثل المرضى المسنين عددًا كبيرًا من السكان الذين يحتاجون إلى رئى رعاية خاصة.

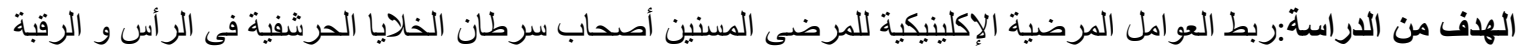
دون البلعوم الأنفى بالبقاء دون ظهور إرتجاع للمرض أو ظهور ثانويات و البقاء البراء على قيد الحياة.

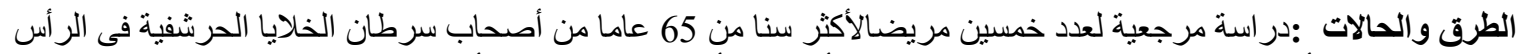

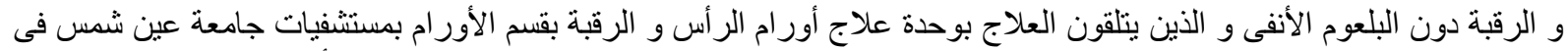

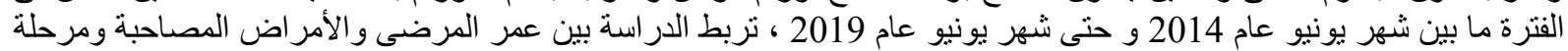

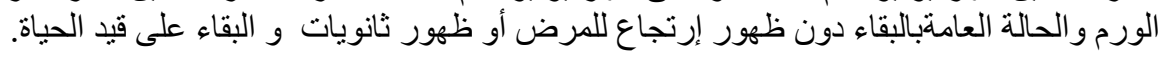

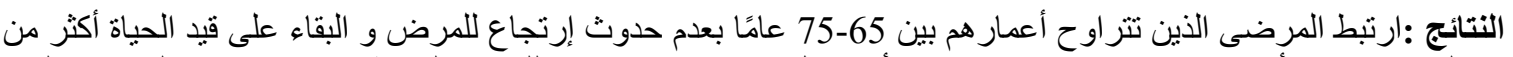

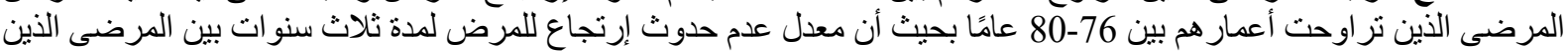

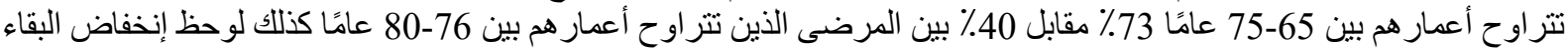

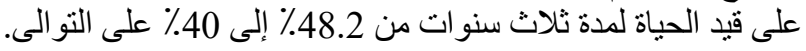

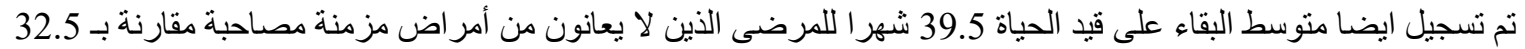

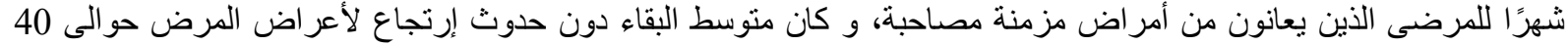
شهر الكلتا المجمو عتين.

تم تسجيل ثلاث سنوات من عدم حدوث إرتجاع للمرض بنسبة 78.7\% للمرضى ذو الحالة العامة الجيدة ، بينما تم تسجيل نسبة 054 54 للحالة العامة المتوسطة و الضعيفة.

و قد تم تسجيل ايضا لثنلاث سنو ات من البقاء على قيد الحياة بنسبة 60.7\% للمرضى ذو الحالة الجيدة، بينما انخفضت النسبة ل 42\% للمرضى ذو الحالة العامة المتوسطة و الضعيفة.

و قد لوحظ إنخفاض معدل عدم إرتجاع المرض من 43.9 شهرًا إلى 18.4 شهرًا للمر احل المبكرة و المتقدمة على الترتيب ولكن بدون ارتباط بدلالة إحصائية.

وجد حدوث إنخفاضفى معدل البقاء على قيد الحياة من 100\% فى المر احل المبكرة إلى 40.3\% للمر احل المتقدمة للمرض.

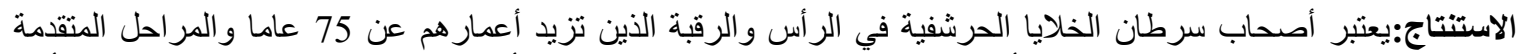

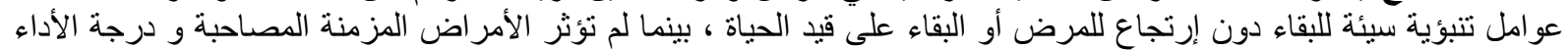

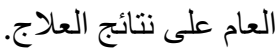

